\title{
PENGEMBANGAN LKPD IPA BERBASIS SERVICE LEARNING UNTUK MENINGKATKAN KEMAMPUAN REFLECTIVE THINKING SISWA
}

\author{
Nindya Puri Setiawati ${ }^{*}$, Bhakti Karyadi ${ }^{1}$, Ariefa Primair Yani ${ }^{1}$ \\ ${ }^{1}$ Program Studi Pendidikan Biologi, Fakultas Keguruan dan Ilmu Pendidikan, Universitas Bengkulu \\ Email: Nindypuri15@gmail.com
}

\begin{abstract}
Abstrak
Penelitian ini bertujuan mengetahui kerangka dan kelayakan LKPD IPA berbasis service learning menurut dosen ahli dan praktisi, serta mengetahui reflective thinking peserta didik setelah belajar dengan menggunakan LKPD IPA berbasis service learning. Jenis penelitian ini adalah Research and Development dengan metode 1) Tahap analisis, 2) perancangan, 3) pengembangan dan produksi, 4) implementasi, dan 5) evaluasi. Data dianalisis secara deskriptif yaitu hasil pengembangan LKPD IPA materi dampak pencemaran lingkungan terdiri atas kerangka umum yang berisi halaman judul, kompetensi, tujuan pembelajaran, peta konsep, dan lembar kegiatan, serta kerangka isi berisi judul, tujuan kegiatan, pengantar materi, alat dan bahan, langkah kerja, tabel dan gambar, pertanyaan diskusi, kesimpulan, dan kolom refleksi. Hasil penilaian validasi dari tim dosen ahli dan praktisi dilihat dari aspek kelayakan isi, kebahasaan, penyajian, dan kegrafikan memberikan hasil 94,75\% sehingga bahan ajar LKPD IPA berbasis service learning yang dikembangkan memiliki kelayakan dengan kategori sangat baik. Hasil pretest-posttest kemampuan reflective thinking peserta didik sebelum dilakukan uji coba LKPD dan setelah peserta didik belajar dengan semua LKPD menunjukkan adanya peningkatan dengan rerata skor 61,4 berkategori kurang menjadi 79,4 berkategori cukup. Berdasarkan penilaian skor hasil tes pretest-posttest kemampuan reflective thinking maka peserta didik telah memiliki kemampuan reflective thinking.
\end{abstract}

Kata kunci : Reflective Thinking, LKPD, Service Learning

\begin{abstract}
This study aims to determine the framework and feasibility of LKPD IPA based on service learning according to expert lecturers and practitioners, and to know reflective thinking of learners after learning by using LKPD IPA based on service learning. This research uses Research and Development is method: 1) Stage analysis, 2) design, 3) development and production, 4) implementation, and 5) evaluation. The data in a analyzed descriptive that is the result of the development of LKPD IPA of material is impact environmental pollution the consisted of a general framework containing title page, competence, learning objectives, concept maps, and activity sheets, and content framework containing the title, activity objectives, material introduction, tools and materials, Work steps, tables and drawings, discussion questions, conclusions, and reflection columns. The result of validation assessment from expert lecturer team and practitioner is seen from feasibility aspect of content, language, presentation, and graph give result $94,75 \%$ so that teaching materials LKPD IPA based service learning with very good category. Pretest-posttest results reflective thinking ability of learners prior to LKPD trial and after learners learn with all LKPD showed an increase with average score of 61.4 categorized less to 79.4 enough categorized. Based on the scores of pretest-posttest test results of reflective thinking ability, the students have reflective thinking ability.
\end{abstract}

Keywords: Reflective Thinking, LKPD, Service Learning 


\section{PENDAHULUAN}

Perubahan kurikulum 2013 menuntut adanya peningkatan dalam proses pembelajaran. Kurikulum 2013 mengubah pendekatan pembelajaran yang berpusat pada guru menjadi pendekatan pembelajaran yang berpusat pada peserta didik. Kurikulum 2013 mengharuskan adanya kegiatan belajar berupa real experience yang menuntut peserta didik untuk melakukan pembelajaran secara otentik. Pembelajaran otentik dapat terjadi ketika guru memberikan kesempatan belajar yang bermakna dan sesuai sehingga peserta didik dapat berpikir ilmiah, memecahkan masalah, berpikir kritis dan merefleksikan masalah dalam kehidupan sehari-hari (Nastiti, 2016).

Salah satu upaya peningkatan proses pembelajaran adalah dengan adanya strategi pembelajaran inovatif. Pembelajaran inovatif salah satunya service learning. Service learning didesain untuk membuat materi pembelajaran yang berhubungan dengan masalah dalam kehidupan nyata (Andersen, 1998).

Service learning menjadikan anak tidak hanya mengerti tentang lingkungan tetapi anak juga merasakan atau terlibat langsung di dalam lingkungan. Service learning juga untuk merespon kebutuhan lingkungan yang bertujuan memberikan pengalaman bermakna pada anak atas apa yang telah ia peroleh dalam pendidikan untuk diterapkan dalam kehidupan nyata di lingkungan (Asyraf dkk, 2014). Selama proses pembelajaran, peserta didik harus mampu membangun pengalaman belajar berdasarkan apa yang peserta didik lakukan selama pembelajaran, maka perlu adanya refleksi setelah pembelajaran yang dilakukan. Salah satunya dengan mengembangkan kemampuan reflective thinking pada diri peserta didik. Kemampuan reflective thinking merupakan suatu kegiatan berpikir yang dapat membuat peserta didik berusaha menghubungkan pengetahuan yang diperolehnya untuk menyelesaikan permasalahan baru yang berkaitan dengan pengetahuan lamanya (Widiawati, 2016). Keterkaitan reflective thinking dengan service learning yaitu sebuah jembatan yang menghubungkan pelayanan dan pembelajaran melalui sebuah proses refleksi (Kuntjara dkk, 2013).

Pembelajaran dengan menggunakan strategi pembelajaran dapat lebih mudah diterapkan guru jika dalam proses pembelajarannya dilengkapi dengan bahan ajar berupa lembar kerja siswa atau lembar kegiatan peserta didik (LKPD). Sebenarnya LKS dengan LKPD sama, hanya penamaannya saja terdapat perbedaan. Menurut Undang-Undang tentang Sistem Pendidikan Nasional Tahun 2003, istilah siswa diganti menjadi peserta didik maka LKPD memiliki pengertian yang sama dengan LKS dalam hal ini LKS dimaksudkan sebagai LKPD. Penyebutan LKS beralih menjadi LKPD disebabkan oleh berkembangnya paradigma pendidikan tentang guru dan siswa.

Berdasarkan hasil observasi di salah satu Sekolah MTs Negeri 2 Kota Bengkulu, ditemukan LKPD IPA yang dipergunakan dalam proses pembelajaran merupakan LKPD yang berisikan rangkuman materi dan latihan-latihan soal untuk dikerjakan oleh peserta didik. LKPD yang digunakan belum menyisipkan fakta atau fenomena yang dapat menggali rasa ingin tahu peserta didik dan belum memberikan kesempatan kepada peserta didik untuk melakukan kegiatan penyelidikan dan pemecahan masalah.

Berdasarkan hal tersebut peneliti bekerja sama dengan guru IPA untuk melakukan penelitian dengan judul penelitian yaitu Pengembangan LKPD IPA Berbasis Service Learning Untuk Meningkatkan Kemampuan Reflective Thinking Siswa. 


\section{METODE}

Rancangan penelitian yang dilakukan adalah menggunakan langkah-langkah metode penelitian dan pengembangan (Research and Develop-ment/R\&D) yang mengacu kepada langkah-langkah model ADDIE (Branch, 2009) yaitu tahap Analisis (Analysis), tahap Perancangan (Design), tahap Pengembangan dan Produksi (Develop-ment and Production), tahap implementasi (Implementation), dan tahap Evaluasi (Evaluation). Subjek penelitian adalah peserta didik kelas $\mathrm{VII}_{\mathrm{A}}$ MTs Negeri 2 Kota Bengkulu berjumlah 20 orang peserta didik. Teknik pengumpulan data menggunakan instrumen validasi, lembar kinerja, dan lembar tes. Teknik analisis data menggunakan teknik deskriptif kualitatif dengan melihat:

1) Skor rata-rata bahan ajar LKPD pada aspek kelayakan isi, kebahasaan, penyajian, dan kegrafikan.

2) Mengkonversikan skor rata-rata menjadi nilai dengan kriteria

Tabel 1. Hasil konversi skor menjadi skala empat

\begin{tabular}{|c|l|c|c|}
\hline No & \multicolumn{2}{|c|}{ Interval Skor } & Kategori \\
\hline 1 & $\mathrm{X}>\overline{\mathrm{X}}_{\mathrm{i}}+1,8 \mathrm{x} \mathrm{SB}_{\mathrm{i}}$ & $\mathrm{X}>62,4$ & $\begin{array}{c}\text { Sangat } \\
\text { Baik }\end{array}$ \\
\hline 2 & $\overline{\mathrm{X}}_{\mathrm{i}}+0,6 \mathrm{x} \mathrm{SB}_{\mathrm{i}}<\mathrm{X} \leq \overline{\mathrm{X}}_{\mathrm{i}}+1,8 \times \mathrm{xSB}_{\mathrm{i}}$ & $52,8<\mathrm{X} \leq 62,4$ & Baik \\
\hline 3 & $\overline{\mathrm{X}}_{\mathrm{i}}-0,6 \times \mathrm{xB}_{\mathrm{i}}<\mathrm{X} \leq \overline{\mathrm{X}}_{\mathrm{i}}+0,6 \mathrm{xSB}_{\mathrm{i}}$ & $43,2<\mathrm{X} \leq 52,8$ & Cukup \\
\hline 4 & $\overline{\mathrm{X}}_{\mathrm{i}}-1,8 \mathrm{x} \mathrm{SB}_{\mathrm{i}}<\mathrm{X} \leq \overline{\mathrm{X}}_{\mathrm{i}}-0,6 \mathrm{xSB}_{\mathrm{i}}$ & $33,6<\mathrm{X} \leq 43,2$ & Kurang \\
\hline
\end{tabular}

(Widoyoko, 2016)

3) Kemudian hasil konversi dipersentasekan untuk mengetahui keidealan tiap aspek

4) Menghitung Persentage of agreement untuk melihat kereabilitasan suatu bahan ajar dengan menggunakan rumus:

$$
\mathrm{PA}=\left\{1-\frac{(A-B)}{(A+B}\right\} 100 \%
$$

(Borich, 1994)

Keterangan:

$\mathrm{PA}=$ Percentage of agreement
$\mathrm{A} \quad=$ Skor tertinggi yang diberikan oleh validator
$\mathrm{B}=$ Skor terendah yang diberikan oleh validator

Analisis kemampuan reflective thinking dapat diketahui dengan:

1) Menghitung rata-rata skor pretestposttest kemampuan reflective thinking

2) Menghitung skor pretest-posttest kemampuan reflective thinking tiap peserta didik dengan menggunakan skor kategori predikat menggunakan nilai KKM di bawah ini.

Tabel 2. Interval nilai dan predikat pretest-posttest kemampuan reflective thinking peserta didik untuk KKM 75

\begin{tabular}{|c|c|c|}
\hline Interval Nilai & Predikat & Kategori \\
\hline$>92-100$ & A & Sangat Baik \\
\hline$>83-91$ & B & Baik \\
\hline$\geq 75-82$ & C & Cukup \\
\hline$<75$ & D & Kurang \\
\hline
\end{tabular}

(Kemendikbud, 2016)

3) Menghitung persentase kategori predikat skor kemampuan reflective thinking peserta didik

\section{HASIL DAN PEMBAHASAN}

\section{Deskripsi Hasil Analisis Instruksional}

Pada tahap ini telah dilakukan analisis kebutuhan bahan ajar yang menjadi proses awal dalam penyusunan LKPD. Analisis kurikulum dilakukan dengan cara mengidentifikasi kompetensi yang mengacu pada kurikulum 2013 mata pelajaran IPA kelas VII semester dua materi dampak pencemaran lingkungan. Hasil analisis kurikulum yaitu kompetensi inti 3 . Memahami pengetahuan (faktual, konseptual, dan prosedural) berdasarkan rasa ingin tahunya tentang ilmu pengetahuan, teknologi, seni, budaya, terkait fenomena, dan kejadian tampak mata dan 4. Mencoba, mengolah, dan menyaji dalam ranah kongret (menggunakan, mengurai, merangkai, memodifikasi, dan membuat) dan ranah abstrak (menulis, membaca, menghitung, menggambar, dan mengarang) sesuai yang dipelajari di sekolah dan sumber lain yang sama dalam sudut pandang teori. Kompetensi Dasar 3.8. Menganalisis terjadinya pencemaran lingkungan dan dampaknya bagi ekosistem 
dan 4.8. Membuat tulisan tentang gagasan penyelesaian masalah pencemaran di lingkungannya ber-dasarkan hasil pengamatan. Hasil penjabaran kompetensi inti dan kompetensi dasar berupa indikator pencapaian yang terdiri dari tujuh indikator pencapaian hasil belajar yaitu (1)Memahami konsep pencemaran lingkungan; (2) Memberi contoh pencemaran yang sering ditemukan di lingkungan sekitar (berasal dari limbah rumah tangga, pabrik, dan pertanian); (3) Memperkirakan jenis pencemaran dari artikel yang dipaparkan; (4) Menyelidiki pengaruh detergen terhadap tingkat keracunan ikan dari hasil percobaan; (5) Menganalisis dampak yang ditimbulkan oleh pencemaran air, udara, dan tanah; (6) Menganalisis upaya yang dapat dilakukan untuk mencegah pencemaran; dan (7) Menyajikan hasil diskusi melalui studi kasus dan percobaan tentang pencemaran lingkungan.

Pemilihan materi dampak pencemaran ini diambil karena di dalam isi materi mencakup permasalahanpermasalahan yang umum ditemukan di kehidupan sehari-hari sehingga pemilihan topik di dalam pembuatan LKPD ini didasarkan atas service learning. Service Learning merupakan strategi pengajaran yang efektif karena merupakan sebuah jembatan yang menghubungkan pelayanan dan pembelajaran melalui sebuah proses refleksi (Kuntjara dkk, 2013). Anak akan belajar melakukan pelayanan untuk merespon kebutuhan lingkungan yang bertujuan untuk memberikan pengalaman bermakna (meaningful learning) atas apa yang telah ia peroleh di sekolah untuk diterapkan dalam kehidupan nyata di lingkungan (Asyraf dkk, 2014). Harapannya jiwa melayani dapat lebih tertanam pada diri peserta didik dan pada akhirnya tindakan untuk melayani semakin dapat terwujud dalam upaya meningkatkannya. Service learning memberikan keuntungan positif bagi perkembangan pribadi peserta didik diantaranya, membantu perkembangan pribadi baik secara personal maupun inter-personal, memahami dan mengaplikasikan pengetahuan mereka, mengembangkan cara berpikir kritis, mengubah cara berpikir dan perspektif, dan membentuk karakter pribadi yang kuat (soft skill) seperti kepedulian, berpikir kreatif dan kritis, leadership, membangun teamwork, dan kemampuan berkomunikasi (Billig, 2000).

\section{Deskripsi Hasil Perancangan dan Pengembangan LKPD}

Berdasarkan Gambar 1. hasil dari perancangan dan pengembangan, terdapat lima unsur kerangka umum LKPD yang dikembangkan berdasarkan service learning yaitu (1) Halaman judul berisikan informasi yang berkaitan dengan pokok materi yang akan dipelajari yaitu materi dampak pencemaran lingkungan dengan alokasi waktu pembelajaran dua kali pertemuan; (2) Kompetensi berisi uraian kompetensi yang akan dipelajari pada LKPD yang terdiri dari Kompetensi Inti dan Kompetensi Dasar berdasarkan atas analisis kurikulum; (3) Tujuan pembelajaran berisikan tujuan pencapaian hasil belajar dari seluruh kegiatan dalam LKPD dan tujuan yang dibuat juga sudah mencerminkan kepada indikator reflective thinking; (4) Peta konsep berisikan rangkaian konsep pengetahuanpengetahuan yang akan dicapai peserta didik dalam menggunakan bahan ajar LKPD; dan (5) Lembar kegiatan menggambarkan keseluruhan isi kegiatan dalam LKPD. Gambaran kerangka umum dan kerangka isi kegiatan LKPD dari hasil pengembangan berbasis service learning disajikan pada gambar di bawah ini. 


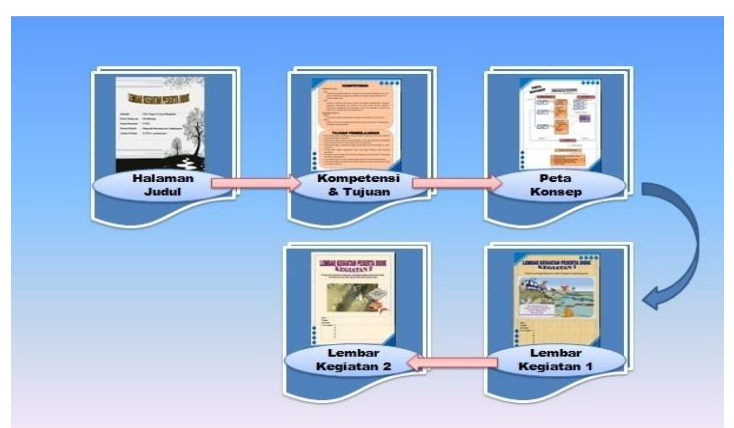

Gambar 1. Kerangka umum LKPD berbasis service learning

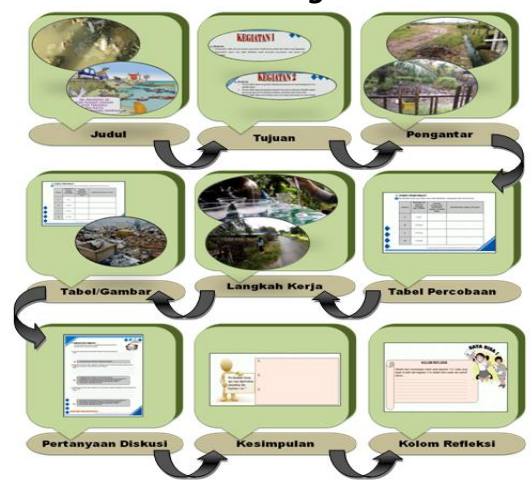

Gambar 2. Kerangka isi kegiatan pada LKPD berbasis service learning

Gambar 2 merupakan kerangka struktur yang terdapat dalam lembar kegiatan LKPD. Kerangka struktur lembar kegiatan yang telah dirancang, terdapat sembilan unsur yang menggambarkan keseluruhan isi kegiatan yang tercakup dalam LKPD yaitu: (1) Judul dalam LKPD berisi informasi umum terjadinya suatu fenomena yang menggambarkan topik permasalahan yang akan dibahas untuk tercapainya suatu kompetensi dasar; (2) Tujuan kegiatan telah termuat indikator reflective thinking sehingga proses kegiatan menjadi terarah karena reflective thinking dapat memunculkan kemampuan analisis peserta didik dalam memecahkan permasalahan yang ada sehingga tujuan pencapaian hasil belajar dapat tercapai; (3) Pengantar materi berisikan informasi umum seputar topik permasalahan yang bertujuan agar peserta didik dapat menemukan arahan yang terstruktur untuk memahami materi yang diberikan.

Materi yang disajikan mengandung indikator service learning karena materi diambil dari permasalahan yang umum ditemukan di masyarakat; (4) Alat dan Bahan yang digunakan dalam kegiatan 1 adalah sebuah artikel yang berisi informasi permasalahan dampak yang ditimbulkan dari tumpukan sampah anorganik dan kegiatan 2 berupa alat dan bahan percobaan tentang pengaruh konsentrasi detergen terhadap tingkat keracunan ikan nila berdasarkan gerak operculum dan kondisi ikan; (5) Langkah kerja yang dibuat disusun berdasarkan atas hasil dari langkah-langkah percobaan uji coba peneliti sehingga langkah kerja yang dibuat memudahkan peserta didik melakukan kegiatan secara berurutan; (6) Tabel dan gambar yang disajikan mengandung informasi pendukung yang memudahkan peserta didik menemukan jawaban atas permasalahan yang memberikan gambaran kepada peserta didik untuk memahami topik/cerita dari permasalahan yang diberikan; (7) Pertanyaan diskusi berisikan pertanyaan yang mengandung permasalahan-permasalahan yang akan dipecahkan oleh kelompok peserta didik secara diskusi yang diambil dari kasuskasus yang menjadi topik permasalahan di dalam LKPD. Setiap butir pertanyaan mengandung indikator reflective thinking yaitu mengekspresikan kesadaran terhadap permasalahan, mengekspresikan hubungan antara konsep pembelajaran dan pengalaman, permasalahan dipecahkan berdasarkan wawasan dan pengalaman, permasalahan yang dipecahkan dapat menjadi bahan evaluasi, dan memunculkan kemampuan analisis sehingga dari persoalan yang disajikan dapat melatih kelompok memiliki kemampuan reflective thinking; (8) Kesimpulan yang sudah dibuat menggambarkan keseluruhan hasil dari tujuan kegiatan yang telah dilakukan oleh peserta didik selama proses kegiatan sehingga tercapainya tujuan pembelajaran; (9) Kolom refleksi berisi hasil pemikiran yang tanpa sengaja 
dituangkan oleh peserta didik sebagai bahan untuk mengevaluasi diri atas makna yang diperolehnya selama pembelajaran berlangsung dan digunakan untuk melihat seberapa jauh perkembangan kemampuan reflective thinking peserta didik.

LKPD yang dibuat dirancang lebih menarik serta lebih kontekstual dengan situasi dan kondisi sekolah ataupun lingkungan sosial budaya peserta didik. Hal ini karena LKPD yang dirancang didasarkan akan service learning. Persoalan dalam service learning merujuk pada 3 indikator service learning menurut The National Center for Service-Learning dalam Kirby (2016) yaitu materi diambil dari permasalahan yang umum ditemukan di masyarakat, solusi masalah didapatkan melalui kombinasi antara ilmu yang telah didapatkan dan pengalaman dimasyarakat sebelumnya, serta permasalahan dan solusi mampu menjadi wadah refleksi. Harapannya ketika peserta didik sudah memiliki konsep yang didapatkan di kelas, peserta didik terdorong untuk memiliki kesadaran akan permasalahan berupa tindakan untuk mengatasi permasalahan yang didapatkan dari kombinasi antara pengetahuan yang telah didapatkan dan dari pengalaman yang didapatkan sebelum konsep diberikan sehingga peserta didik dapat memahami konsep yang didapatkannya untuk mengaplikasi-kan ilmunya tersebut guna merespon kebutuhan lingkungan.

\section{Hasil Validasi LKPD IPA Berbasis Service Learning}

Hasil rata-rata skor validasi LKPD IPA berbasis service learning yang di kembangkan dilihat dari aspek kelayakan isi, kebahasaan, penyajian, dan kegrafikan oleh tim dosen ahli dan praktisi (guru memberikan hasil 94,75\%" maka dapat disimpulkan bahwa produk LKPD yang dikembangkan berdasarkan atas service learning ini dinilai "Sangat Layak" oleh keempat validator sehingga produk LKPD hasil pengembangan ini sangat layak di ujicobakan kepada peserta didik.

\section{Uji Coba produk LKPD Berbasis Service Learning}

Hasil penilaian skor kinerja kelompok aspek kongnitif terhadap LKPD pada kegiatan 1 dan kegiatan 2 disajikan pada tabel di bawah ini.

Tabel 3. Hasil penilaian skor kinerja kelompok aspek kongnitif terhadap LKPD pada kegiatan 1 dan kegiatan 2

\begin{tabular}{|c|c|c|c|}
\hline No & Nama & \multicolumn{2}{|c|}{ Skor LKPD pada } \\
\cline { 3 - 4 } & Kelompok & Kegiatan & Kegiatan \\
& & $\mathbf{1}$ & $\mathbf{2}$ \\
\hline 1. & Kelompok 1 & 80,5 & 88 \\
\hline 2. & Kelompok 2 & 60,5 & 93 \\
\hline 3. & Kelompok 3 & 77,5 & 83 \\
\hline 4. & Kelompok 4 & 77,5 & 93 \\
\hline \multicolumn{2}{|l}{ Rata-rata skor } & $\mathbf{7 4}$ & $\mathbf{8 9 , 2 5}$ \\
\hline
\end{tabular}

Berdasarkan Tabel 4, Hasil penilaian kinerja kelompok terhadap LKPD pada kegiatan 1 berada pada kategori cukup dengan rerata skor 74 , dari hasil penelitian yang didapatkan terdapat hasil kinerja yang belum optimal dari peserta didik. Permasalahan tersebut berada pada persoalan yang disajikan dalam LKPD menghadirkan situasi kongrit ke dalam pembelajaran yang mengharuskan peserta didik untuk memahami persoalan yang kompleks harapannya agar peserta didik terdorong untuk memahami hubungan pencemaran lingkungan dan dampaknya. Namun, pemberian persoalan yang kompleks belum mampu untuk dipahami oleh peserta didik dikarenakan persoalan yang diberikan terlalu tinggi untuk dipahami oleh peserta didik. Hal ini sesuai dengan pendapat piaget bahwa perkembangan kongnitif anak saat menginjak umur 11-12 tahun berada pada tahap operasi konkrit dimana seorang anak mengarah pada kejadian konkrit yang dapat diamati pada saat itu, anak masih terikat kepada pengalaman pribadi yang 
masih konkret, anak belum mampu melakukan problem yang bersifat abstrak (Ibda, 2015). Artinya untuk anak tingkat SMP perkembangan intelektualnya masih terbatas pada persoalan yang bersifat kongrit dengan pemberian permasalahan yang sederhana. Menindaklanjuti hal tersebut, peneliti memberikan permasalahan sama namun dengan metode yang berbeda yaitu memberikan permasalahan kongrit melalui percobaan di dalam LKPD pada kegiatan 2 sehingga anak terlibat langsung dalam kegiatan. Menurut piaget, menciptakan kegiatan belajar yang dapat menantang anak mencapai tahap perkembangan berikut-nya. Artinya dengan memberikan per-masalahan yang melibatkan langsung anak untuk ikut melakukan kegiatan dapat memberikan kesempatan bagi anak untuk memperoleh pengalaman langsung dari lingkungan sehingga dapat membentuk skema baru dalam struktur kognitifnya. Hasilnya kinerja kelompok terhadap LKPD pada kegiatan 2 membaik yaitu 89,25 dengan kategori baik, artinya kinerja kelompok terhadap LKPD yang dikerjakan peserta didik sebagai proses dalam melatih kemampuan reflective thinking dengan melihat kinerjanya dalam mengerjakan suatu diskusi kelompok sudah mengalami peningkatan sehingga hasil kinerjanya dalam mengerjakan kegiatan di dalam LKPD sudah Baik. Hal ini sesuai dengan salah satu indikator berfikir kritis dari Ennis (1993) bahwa terdapat aspek menentukan strategi dalam bentuk argument. Sesuai pendapat tersebut maka membangun argument didapatkan dari kelompok peserta didik yang berdiskusi dalam memecahkan suatu permasalahan dari pengerjaan semua kegiatan yang ada di dalam LKPD untuk mendorong kelompok peserta didik memiliki kemampuan tingkat tinggi yaitu kemampuan reflective thinking.

\section{Deskripsi Hasil Pretest dan Posttes Kemampuan Reflective Thinking}

Secara keseluruhan kemampuan reflective thinking peserta didik sebelum dilakukan uji coba LKPD dengan menggunakan tes pretest tergolong dalam kategori kurang dengan rata-rata skor 61,4. Kemampuan reflective thinking setelah peserta didik belajar dengan semua LKPD yang ada dengan menggunakan tes posttest meningkat menjadi tergolong dalam kategori cukup dengan rerata skor 79,4. Hasil rata-rata skor pretest-posttest kemampuan reflective thinking peserta didik disajikan pada tabel di bawah ini.

Tabel 4. Hasil rerata skor pretest-posttest kemampuan reflective thinking tiap peserta didik

\begin{tabular}{|l|l|l|}
\hline \multirow{2}{*}{ Tes } & \multicolumn{2}{|c|}{$\begin{array}{c}\text { Hasil Kemampuan } \\
\text { Reflective Thinking Peserta } \\
\text { Didik }\end{array}$} \\
\cline { 2 - 3 } & $\begin{array}{c}\text { Rata-rata } \\
\text { Skor }\end{array}$ & \multicolumn{1}{|c|}{ Kategori } \\
\hline Pretest & 61,4 & Kurang \\
\hline Posttest & 79,4 & Cukup \\
\hline
\end{tabular}

Peningkatan kemampuan reflective thinking peserta didik dengan tes pretestposttest disebabkan karena hasil kinerjanya dalam mengerjakan kegiatan di dalam LKPD sudah Baik sehingga anak sudah memiliki bekal untuk dilatih memiliki kemampuan reflective thinking. Melalui persoalan yang diberikan di dalam pretest-posttest yang dikembangkan berdasarkan indikator reflective thinking dapat me-nuntun peserta didik dalam belajar dan menuntun peserta didik dalam memahami konsep dampak pencemaran lingkungan sehingga peserta didik terarah untuk aktif dalam menemukan konsep. Berikut adalah gambar grafik peningkatan ke-mampuan reflective thinking peserta didik pada tes pretest-posttest. 


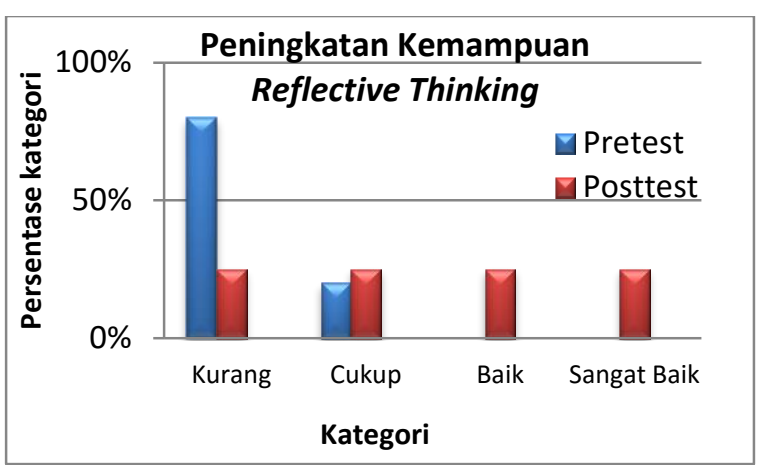

Gambar 3. Grafik peningkatan kemampuan reflective thinking peserta didik pada tes pretest-posttest

Berdasarkan grafik diatas, dari 20 orang peserta didik yang mengikuti test pretest hanya $20 \%$ peserta didik yang mendapatkan skor dengan kategori cukup dan $80 \%$ peserta didik mendapatkan skor dengan kategori kurang. Permasalahan tersebut berada pada permasalahan dampak yang memungkinkan timbulnya pencemaran yang dipecahkan berdasarkan wawasan dan pengalaman belum dikuasai oleh peserta didik, permasalahan yang di pecahkan belum dapat mengarahkan peserta didik untuk mengevaluasi diri dalam memberikan upaya dalam mengatasi permasalahan, serta peserta didik belum mampu memecahkan permasalahan yang dapat memunculkan kemampuan analisisnya. Hal ini disebabkan karena permasalahan yang akan dipecahkan peserta didik dalam test pretest mengarah pada indikator reflective thinking yang menuntut peserta didik untuk berfikir tingkat tinggi. Kenyataannya, perkembangan intelektual anak masih terbatas pada persoalan yang bersifat kongrit dengan pemberian permasalahan yang sesuai dengan tingkat perkembangan anak. hal ini sesuai dengan teori piaget yang menyatakan bahwa perkembangan kongnitif anak saat menginjak umur 11-12 tahun berada pada tahap operasi konkrit dimana seorang anak mengarah pada kejadian konkrit yang dapat diamati pada saat itu, anak masih terikat kepada pengalaman pribadi yang masih konkret, anak belum mampu melakukan problem yang bersifat abstrak (Ibda, 2015). Artinya untuk anak usia menginjak remaja, perkembangan kemampuan berfikir anak belum sampai pada tingkat yang lebih tinggi namun dengan persoalan yang diberikan harapannya dapat melatih kemampuan tingkat tinggi peserta didik yaitu salah satunya reflective thinking.

Hasil penilaian test posttest memberikan hasil yang membaik yaitu hanya $5 \%$ peserta didik saja yang masingmasing mendapatkan skor kurang dan cukup. Hal tersebut dikarenakan hasil kinerjanya dalam mengerjakan kegiatan di dalam LKPD sudah Baik sehingga anak sudah memiliki bekal untuk dilatih memiliki kemampuan reflective thinking. Artinya cara berfikir anak telah mencapai tahap perkembangan berikutnya dalam membentuk skema baru dalam struktur kognitifnya.

\section{PENUTUP}

\section{Simpulan}

1. LKPD IPA yang dikembangkan berdasarkan atas service learning pada materi dampak pencemaran lingkungan terdiri atas lima unsur kerangka umum yaitu halaman judul, kompetensi, tujuan pembelajaran, peta konsep, dan lembar kegiatan, serta terdapat sembilan unsur kerangka isi yang menggambarkan keseluruhan isi kegiatan pada LKPD yaitu judul, tujuan kegiatan, pengantar materi, alat dan bahan, prosedur kegiatan, tabel dan gambar, pertanyaan diskusi, kesimpulan, dan kolom refleksi.

2. LKPD hasil pengembangan dinyatakan layak oleh tim dosen ahli dan tim praktisi (guru) karena memberikan hasil 94,75\% dengan kategori sangat baik untuk diuji coba kepada peserta didik di MTs Kelas VII.

3. Pembelajaran dengan menggunakan LKPD IPA hasil pengembangan service 
learning dapat meningkatan reflective thinking peserta didik hal ini dapat dilihat dari rerata skor kemampuan reflective thinking peserta didik sebelum dilakukan uji coba LKPD dan setelah peserta didik belajar dengan semua LKPD menunjukkan adanya peningkatan hasil dengan rerata skor 61,4 berkategori kurang menjadi 79,4 berkategori cukup

\section{Saran}

1. Pembuatan soal tes kemampuan reflective thinking sebaiknya dibuat dengan butir soal tes yang identik antara soal tes pretest-posttest sehingga hasil yang diperoleh terlihat jelas peningkatan nilai berdasarkan kriteria peningkatan nilai reflective thinkingnya dengan menggunakan gains score.

2. Bagi peneliti lanjutan agar dapat melakukan pengembangan terhadap indikator reflective thinking dengan cara mengembangkan indikator-indikator yang lebih tinggi lagi namun disesuaikan dengan tingkat perkembangan peserta didik.

\section{DAFTAR PUSTAKA}

Andersen, Susan M. 1998. Service Learning: A National Strategy for Youth Development. http://gwdspace.wrlc.org, diakses 08 Februari 2017

Asyraf, Lathifah., Syamsudin, Muhammad Munif., \& Karsono. 2014. Efek Metode Service Learning Terhadap Kemandirian Anak. http://www.jurnal.fkip.uns.ac.id, diakses 08 Februari 2017

Billig, Shelley H. 2000. Research on K-12 School-Based Service Learning: The Evidence Builds. USA: Denver. http://search.proquest.com, diakses 20 Februari 2017
Borich, Gary D. 1994. Observation Skills for Effective Teaching. The University of Texas: USA

Branch, Robert Maribe. 2009. Instructional Design: The ADDIE Approach. www.springer.com, diakses 08 Februari 2017

Ennis, Robert H. 1993. Critical Thinking Assessment.http://faculty.education.illinoi s.edu, diakses 08 Februari 2017

Ibda, Fatimah. 2015. Perkembangan Kognitif: Teori Jean Peaget. (Artikel Jurnal Intelektualita, Vol.3 (1), (http://jurnal.arraniry.ac.id,diakses 08 Februari 2017)

Kemendikbud. 2016. Panduan Penilaian oleh Pendidik dan Satuan Pendidikan untuk Sekolah Menengah Pertama. Jakarta: Kementerian Pendidikan dan Kebudayaan (Salinan)

Kirby. 2016. Service Learning Definitions and Benefits : What is Service Learning, (https://provost.wayne.edu, diakses 27 Januari 2017)

Kuntjara, Esther., Palit, Herry., Arifin, Lilianny Sigit., Natadjaja, Listia., \& Cahyono, Yohanes Budi. 2013. Panduan Pelaksanaan Service Learning. http://Ippm.petra.ac.id, diakses 08 Februari 2017

Nastiti, Chusnindiyah Sari., \& Nurohman, Sabar. 2016. Pengembangan LKPD Materi Sistem Ekskresi Pada Ginjal untuk Mengembangkan Kemampuan Pemecahan Masalah dan Sikap Ingin Tahu Peserta Didik Kelas VIII SMPN 1 Piyungan. http://www. journal.student.uny.ac.id, diakses 10 Februari 2017

Undang-Undang Republik Indonesia Nomor 20 Tahun 2003 Tentang Sistem Pendidikan Nasional (Salinan)

Widiawati, Restu. 2016. Kemampuan Berpikir Reflektif Siswa dalam Memecahkan Masalah Matematika Pada 
Materi Sistem Persamaan Linier Dua Variabel (SPLDV) Berdasarkan Gender Kelas VIII di MTs Negeri Tanjunganom. http://www.simki.unpkediri.ac.id, diakses 28 Januari 2017

Widoyoko, Eko Putro. 2016. Evaluasi Program Pembelajaran: Panduan Praktis Bagi Pendidik dan Calon Pendidik. Yogyakarta: Pustaka Pelajar 